\title{
Differential regulation of the anti-crossover and replication fork regression activities of Mph1 by Mte1
}

\author{
Xiaoyu Xue, ${ }^{1}$ Alma Papusha, ${ }^{2}$ Koyi Choi, ${ }^{3}$ Jacob N. Bonner, ${ }^{3}$ Sandeep Kumar, ${ }^{2}$ Hengyao Niu, ${ }^{1,6}$ \\ Hardeep Kaur, ${ }^{4}$ Xiao-Feng Zheng, ${ }_{1}^{1,7}$ Roberto A. Donnianni, ${ }^{5}$ Lucy Lu, ${ }^{1}$ Michael Lichten, ${ }^{4}$ Xiaolan Zhao, ${ }^{3}$ \\ Grzegorz Ira, ${ }^{2}$ and Patrick Sung ${ }^{1}$ \\ ${ }^{1}$ Department of Molecular Biophysics and Biochemistry, Yale University School of Medicine, New Haven, Connecticut 06520, \\ $\mathrm{USA}_{;}{ }^{2}$ Department of Molecular and Human Genetics, Baylor College of Medicine, Houston, Texas 77030, USA; ${ }^{3}$ Molecular \\ Biology Program, Memorial Sloan Kettering Cancer Center, New York, New York 10065, USA; ${ }^{4}$ Laboratory of Biochemistry and \\ Molecular Biology, Center for Cancer Research, National Cancer Institute, Bethesda, Maryland 20892, USA; ${ }^{5}$ Department of \\ Microbiology and Immunology, Columbia University Medical Center, New York, New York 10032, USA
}

We identified Mte1 (Mph1-associated telomere maintenance protein 1) as a multifunctional regulator of Saccharomyces cerevisiae Mph1, a member of the FANCM family of DNA motor proteins important for DNA replication fork repair and crossover suppression during homologous recombination. We show that Mte1 interacts with Mph1 and DNA species that resemble a DNA replication fork and the D loop formed during recombination. Biochemically, Mte1 stimulates Mph1-mediated DNA replication fork regression and branch migration in a model substrate. Consistent with this activity, genetic analysis reveals that Mte1 functions with Mph1 and the associated MHF complex in replication fork repair. Surprisingly, Mte1 antagonizes the D-loop-dissociative activity of Mph1-MHF and exerts a procrossover role in mitotic recombination. We further show that the influence of Mte1 on Mph1 activities requires its binding to Mph1 and DNA. Thus, Mte1 differentially regulates Mph1 activities to achieve distinct outcomes in recombination and replication fork repair.

[Keywords: Mph1; Mte1; MHF; homologous recombination; genome replication; crossover formation]

Supplemental material is available for this article.

Received December 8, 2015; revised version accepted February 17, 2016.

Fanconi anemia (FA) is a multigenic disease marked by developmental abnormalities, progressive bone marrow failure, and cancer predisposition (Wang and Smogorzewska 2015). Despite excellent progress in identifying FA proteins and their functions, much remains to be learned about how the activities of these proteins are regulated (Kim and D'Andrea 2012; Kottemann and Smogorzewska 2013; Longerich et al. 2014; Wang and Smogorzewska 2015). FANCM is one of the highly conserved core FA proteins (Meetei et al. 2005; Mosedale et al. 2005). FANCM and its orthologs, including the Saccharomyces cerevisiae Mph1 and Schizosaccharomyces pombe Fmll proteins, have been implicated in DNA replication fork $(\mathrm{RF})$ repair (Scheller et al. 2000; Schurer et al. 2004; Sun et al. 2008; Rosado et al. 2009; Singh et al. 2009; Luke-Glaser et al.

Present addresses: ${ }^{6}$ Department of Molecular and Cellular Biochemistry, Indiana University, Bloomington, IN 47405, USA, ${ }^{7}$ Department of Radiation Oncology, Harvard Medical School, Dana-Farber Cancer Institute, Boston, MA 02215, USA.

Corresponding authors: patrick.sung@yale.edu, zhaox1@mkscc.org, gira@ bcm.edu

Article published online ahead of print. Article and publication date are online at http://www.genesdev.org/cgi/doi/10.1101/gad.276139.115.
2010; Schwab et al. 2010; Whitby 2010; Blackford et al. 2012; Xue et al. 2014). In addition, these proteins are needed for the prevention of crossover (CO) formation during DNA double-strand break (DSB) repair by homologous recombination (HR) (Mosedale et al. 2005; Sun et al. 2008; Bakker et al. 2009; Prakash et al. 2009; Rosado et al. 2009).

Several studies have provided insights into how FANCM, Mph1, and Fmll execute their RF repair and anti-CO functions and how some of their activities are regulated to achieve the desired outcome (Schurer et al. 2004; Gari et al. 2008a,b; Sun et al. 2008; Prakash et al. 2009; Singh et al. 2010; Yan et al. 2010; Zheng et al. 2011; Xue et al. 2014, 2015a,b). Results from biochemical and genetic studies have furnished evidence that these motor proteins convert stalled RFs into a "chicken foot" structure, which can be further processed

(C) 2016 Xue et al. This article is distributed exclusively by Cold Spring Harbor Laboratory Press for the first six months after the full-issue publication date (see http://genesdev.cshlp.org/site/misc/terms.xhtml). After six months, it is available under a Creative Commons License (Attribution-NonCommercial 4.0 International), as described at http:// creativecommons.org/licenses/by-nc/4.0/. 
to recruit the Rad51 recombinase to initiate HR (Xue et al. 2015b). In their anti-CO role, FANCM, Mph1, and Fmll dissociate the D-loop intermediate made by the Rad51 recombinase (Gari et al. 2008a; Sun et al. 2008; Prakash et al. 2009). As such, these motor proteins commit the homology-directed DNA repair process through the DNA synthesis-dependent single-strand annealing (SDSA) pathway that generates non-CO (NCO) products exclusively (Mosedale et al. 2005; Sun et al. 2008; Bakker et al. 2009; Deans and West 2009; Prakash et al. 2009; Rosado et al. 2009; Xue et al. 2015b). This function of FANCM/Mph1/Fml1 is thought to prevent COs that can lead to translocations or loss of heterozygosity (Wyatt and West 2014).

Several regulators of FANCM/Mph1/Fml1 have been found, most notably the MHF complex that harbors the histone fold proteins Mhf1 and Mhf2 and the S. cerevisiae Smc5-Smc6 complex of the structural maintenance of chromosome (Smc) protein family (Xue et al. 2015b). MHF in humans and $S$. pombe preferentially binds branched DNA species and associates with FANCM and Fml1, and human MHF enhances the RF regression and DNA branch migration activities of FANCM. Corroborating these biochemical attributes, MHF functions with FANCM and Fml1 in RF repair in vivo (Singh et al. 2010; Yan et al. 2010; Bhattacharjee et al. 2013). Interestingly, S. cerevisiae MHF (ScMHF) does not bind DNA or influence any of the known Mphl enzymatic activities even though it physically interacts with the latter (Xue et al. 2015a). However, ScMHF helps overcome the inhibitory effect of Smc5-Smc6 on RF regression and DNA branch migration in vitro (Xue et al. 2015a). In vivo studies have suggested that Mph1 is subject to negative regulation by Smc5-Smc6 so as to prevent the accumulation of toxic HR intermediates stemming from Mph1-mediated processing of damaged RFs (Chen et al. 2009; Choi et al. 2010; Chavez et al. 2011; Xue et al. 2014, 2015b). Smc5/ 6 acts by preventing the assembly of Mph1 oligomers at the DNA junction of RF substrates, while MHF can overcome this inhibitory effect through competing with Smc5-Smc6 for Mph1 binding (Xue et al. 2014, 2015a). Neither ScMHF nor Smc5/6 affects the anti-CO function of Mph1, suggesting that they are situation-specific regulators of the motor protein.

In this study, we identified a novel Mph1-associated protein, Mte1 (Mph1-associated telomere maintenance protein 1), which forms a stable complex with Mph1 both in vivo and in vitro. We found that purified Mtel preferentially binds branched DNA structures, showing the highest affinity for the D loop, Holliday junction $(\mathrm{HJ})$, and RF. Furthermore, Mte1 stimulates the RF regression activity of Mph1 in vitro, and this corroborates its functions in Mph1-mediated RF repair in cells. Unexpectedly, Mtel antagonizes Mph1-mediated anti-CO function in mitotic cells. Mechanistically, this effect of Mte1 stems from its ability to protect the Rad51-made D loop from dissociation by Mph1. The functional attributes of Mtel are reliant on DNA binding and Mph1 interaction. Our results showing a differential influence of Mtel on the DNA motor activities of Mph1 have important impli- cations for the mitotic and meiotic roles of Mte1 homologs in other organisms.

\section{Results \\ Association of Mte1 with Mph1 and MHF in cells}

We have been interested in identifying protein factors that function with Mph1. For this purpose, we carried out affinity purification of Mph1 TAP-tagged at the endogenous gene locus (Rigaut et al. 1999). Mass spectrometry analysis of the material copurifying with the TAP-tagged Mph1 revealed proteins encoded by YGR042W and YOLO86W-A (Supplemental Fig. S1A). YOL086W-A encodes Mhf1, a component of the MHF complex that also harbors Mhf2 (Xue et al. 2015a). YGR042W encodes a previously uncharacterized protein and was recently named Mte1 in the Saccharomyces Genome Database.

To further verify that Mtel is associated with Mph1 and MHF in cells, we constructed a strain that harbors chromosomally TAP-tagged MHF1 and conducted affinity purification of the tagged protein. Both Mph1 and Mte1 copurified with Mhf1 and Mhf2 (Fig. 1A). These results provide additional evidence for the existence of a Mph1MHF-Mte1 complex in cells.

Assembly of a stoichiometric complex of Mph1, MHF, and Mte 1

We previously described the expression of Mph1 and MHF in insect cells and their purification (Fig. 1B, lanes 1,3; Xue et al. 2014, 2015a). In this study, we expressed GST-tagged Mte1 in insect cells and devised a procedure to purify it to near homogeneity (Fig. 1B, lanes 2, GST tag having been cleaved off by TEV protease). We used two different approaches to show that Mtel forms complexes with Mph1 and MHF. First, affinity pull-down experiments revealed a direct interaction of Mte1 with Mph1 or Mph1MHF but not MHF (Fig. 1C). As expected (Xue et al. 2015a), MHF associated with Mph1 in the affinity pulldown (Fig. 1D). Next, we could purify stoichiometric complexes of Mph1-MHF and Mph1-MHF-Mte1, but not Mph1-Mte1 (Fig. 1B; Supplemental Fig. S1B), when we mixed insect cells expressing Mph1, MHF, or Mte1 before protein purification, including size exclusion chromatography, to assess complex formation (see the Materials and Methods). Taken together, these results indicate that Mte1 directly interacts with Mph1, but stable association between the two proteins requires MHF.

\section{Genetic evidence for epistasis among mte $1 \Delta$, $\operatorname{mph} 1 \Delta$, and $\operatorname{mhf} \Delta$}

Next, we conducted in vivo tests to understand how Mte1 affects Mph1 functions. We showed previously that Mph1 and MHF render smc6 mutants sensitive to methyl methanesulfonate (MMS), which damages DNA and interferes with DNA replication (Xue et al. 2015a). Importantly, we found that mte $1 \Delta$ also suppresses the MMS sensitivity of the smc6-P4 mutant and that the degree of suppression 
A

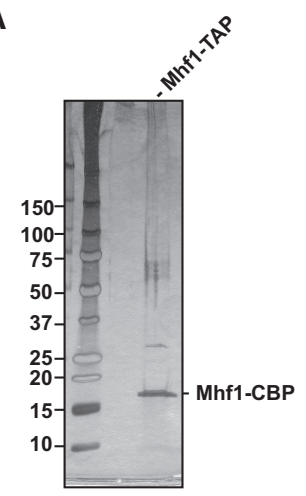

\# of peptide matches Protein Uncharacterized protein YDL160C-A (Mhf2) Putative ATP-dependent helicase YIR002C (Mph1) Uncharacterized protein YOL086W-A (Mhf1) Uncharacterized protein YGR042W (Mte1)

B

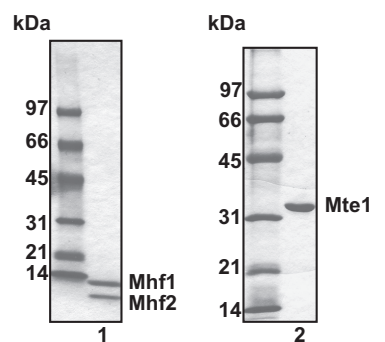

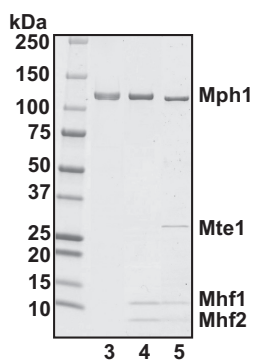

C GST pull down

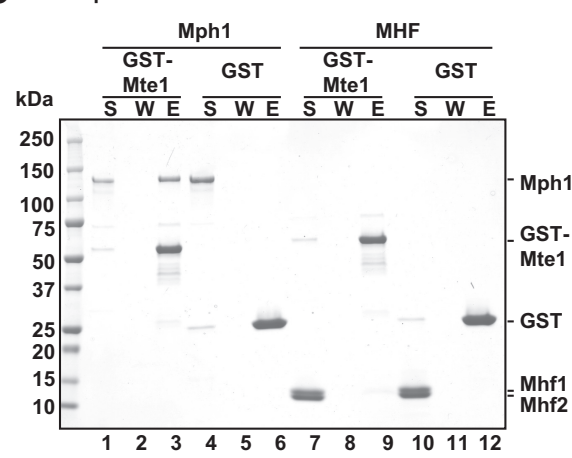

D Flag pull down

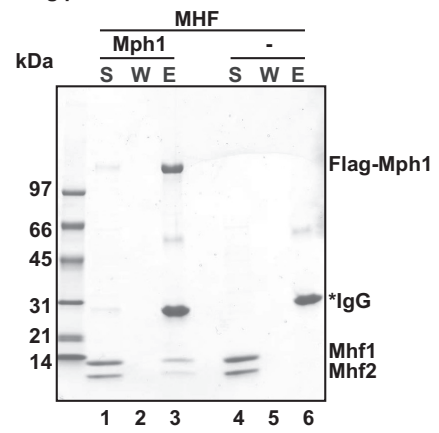

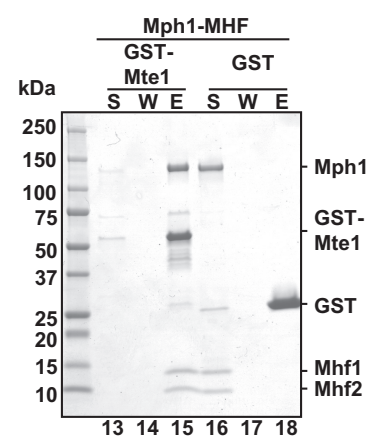

131415161718
Figure 1. Interaction of Mtel with the Mph1-MHF complex. (A) Identification of the Mph1-MHF-Mte1 complex by affinity purification. A TAP affinity tag was added to the $3^{\prime}$ end of the MHF1 gene (YOLO86W$A)$ at its chromosomal locus, and tandem affinity purification was carried out (Rigaut et al. 1999). The purified fraction was treated with trichloroacetic acid (TCA) to precipitate proteins and then analyzed by SDSPAGE and silver staining (left) as well as liquid chromatography-tandem mass spectrometry. The identified proteins and number of peptide matches are listed. $(B) \mathrm{Pu}-$ rified MHF (comprising Mhf1-Mhf2), Mte1, Mph1, the Mph1-MHF complex, and the Mph1-MHF-Mte1 complex were analyzed by SDS-PAGE with Coomassie blue staining. (C) GST pull-down experiments showing that Mte1 interacts with Mph1 alone (lanes 3,6) and the Mph1-MHF complex (lanes 15,18) but not MHF alone (lanes 9,12). (S) Supernatant; (W) wash; (E) SDS eluate. (D) AntiFlag pull-down showing that MHF interacts with Mph1. was similar to that by $m h f \Delta$ but less than that by $m p h 1 \Delta$ (Fig. 2A). Importantly, comparison of the MMS sensitivity of mutants deficient in MHF, Mte1, or Mph1 alone or in various combinations in the smc6-P4 background revealed epistasis among these proteins (Fig. 2B). This notion is further supported by examining $\mathrm{Smc}^{+}$cells lacking each member of the Mph1-MHF-Mte1 complex: mph1s cells were the most sensitive to MMS /Scheller et al. 2000; Schurer et al. 2004), followed by mte1 $\Delta$ and $m h f \Delta$, and any double and triple mutants tested were no more sensitive than $m p h 1 \Delta$, indicative of epistasis among these mutants in the haploid state (Fig. 2C). We also found that $m t e 1 \Delta$ has no impact on the MMS sensitivity of $m p h 1 \Delta$ in diploid cells, again indicative of an epistatic relationship between the two mutations (Fig. 2D).

As sensitivity of mte $1 \Delta$ cells to MMS is seen only at moderate to high concentrations $(0.03 \%-0.05 \%)$ of the chemical, we considered the possibility that the biological function of Mte1, like in the case of Mph1, can be com- pensated for by other genome maintenance pathways. We and others showed previously that the MMS sensitivity of $m p h 1 \Delta$ cells is enhanced by deleting either Sgs1 or Srs2, helicases that are involved in RF and DNA damage repair (Chen et al. 2009; Daee et al. 2012). Importantly, we found that the mte1 $1 \Delta g s 1 \Delta$ and mte1 $1 \Delta$ srs $2 \Delta$ double mutants are significantly more sensitive to low concentrations $(0.005 \%-0.02 \%)$ of MMS than the single mutants (Fig. 2E,F).

Taken together, the genetic analyses suggest that Mte1 functions with Mph1-MHF in chromosome damage repair, raising the possibility that it regulates the activities of the latter.

\section{Promotion of CO formation by Mte1 in mitotic cells}

Besides regulating RF repair, Mph1 also prevents CO formation in mitotic cells by channeling the D-loop intermediate into the SDSA pathway that leads to NCO products 
A

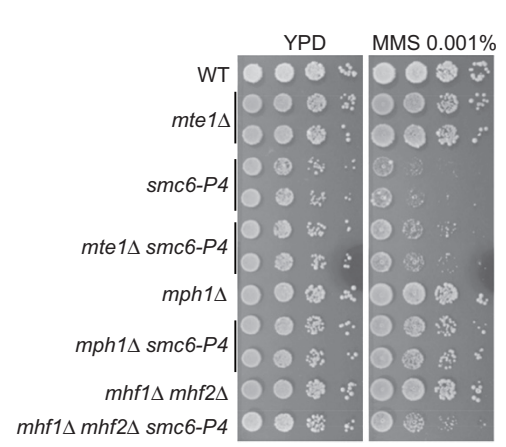

B

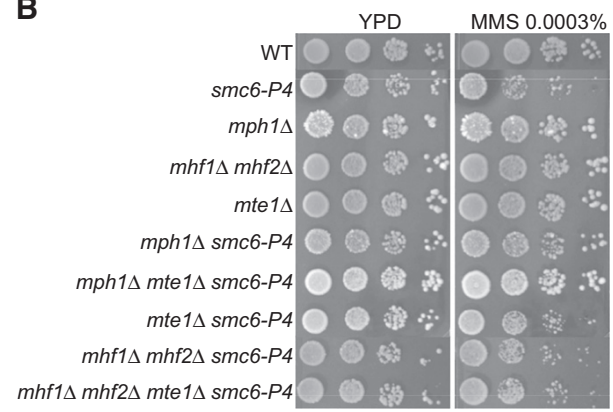

C

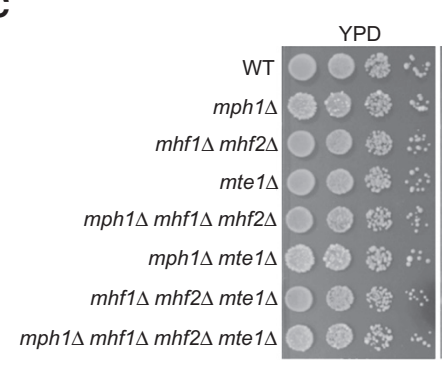

E

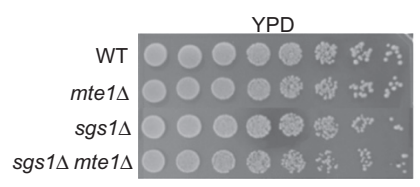

MMS $0.03 \%$

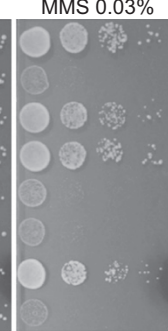

MMS $0.05 \%$

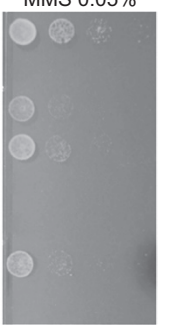

D

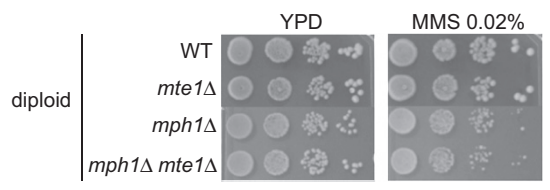

F

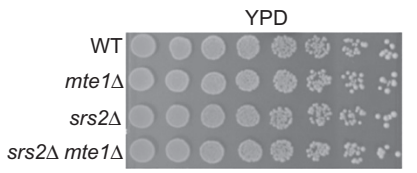

Figure 2. Epistasis analysis of $m t e 1 \Delta, m p h 1 \Delta$, and $m h f \Delta$. (A) Analysis of the $m t e 1 \Delta, m p h 1 \Delta$, and $m h f \Delta$ mutations for the suppression of the MMS sensitivity of smc6 mutant cells. $(B)$ Epistatic relationship among the $m t e 1 \Delta, m p h 1 \Delta$, and $m h f \Delta$ mutations in the suppression of the MMS sensitivity of smc6 mutant cells. (C) MMS sensitivity of $m t e 1 \Delta$ cells and the epistatic relationship of the $m t e 1 \Delta$ mutation to the $m p h 1 \Delta$ and $m h f \Delta$ mutations in haploid cells. $(D)$ MMS sensitivity of $m t e 1 \Delta$ cells and the epistatic relationship of the $m t e 1 \Delta$ mutation to the $m p h 1 \Delta$ mutation in diploid cells. (E) MMS sensitivity of the $m$ te $1 \Delta$ and $s g s 1 \Delta$ single mutants and the $m t e 1 \Delta$ sgs $1 \Delta$ double mutant. $(F)$ MMS sensitivity of the $m t e 1 \Delta$ and srs $2 \Delta$ single mutants and the mte $1 \Delta$ srs $2 \Delta$ double mutant. $(A-C)$ Tenfold serial dilutions of haploid cells. $(D)$ Tenfold serial dilutions of diploid cells. $(E, F)$ Threefold serial dilutions of haploid cells.

only (Prakash et al. 2009; Xue et al. 2015a). To examine whether Mtel affects the ability of Mph1 to regulate the $\mathrm{CO}$ :NCO ratio during the repair of a site-specific DSB, we used an ectopic HR system in which a DSB induced by the HO endonuclease in the MATa sequence on chromosome $\mathrm{V}$ is repaired using the MATa-inc donor sequence on chromosome III (Fig. 3A; Prakash et al. 2009; Xue et al. 2015a). The CO and NCO products can be easily discerned by size in Southern blot analysis (Prakash et al. 2009; Xue et al. 2015a). As expected, the mph1s mutant exhibited a sixfold increase in the CO level compared with wild-type cells. Surprisingly, mte1s cells showed a twofold decrease of the CO level (Fig. 3B; Supplemental Fig. S2), indicating that Mte1 promotes CO formation. Importantly, this CO-promoting activity of Mtel was evi-

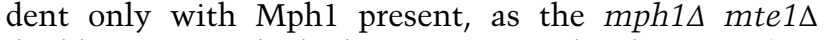
double mutant had the same CO level as mph1s (Fig. 3B; Supplemental Fig. S2).

Two other DNA motor proteins-namely, Srs2 and Sgs1-also suppress CO formation in the budding yeast but via mechanisms distinct from that dependent on Mph1 (Fig. 3B; Supplemental Fig. S2; Ira et al. 2003; Krejci et al. 2003; Wu and Hickson 2003; Prakash et al. 2009; Cejka et al. 2010; Niu et al. 2010). Importantly, the CO level in sgs $1 \Delta$ and srs $2 \Delta$ cells was also reduced by about twofold upon deletion of MTE1 (Fig. 3B; Supplemental Fig. S2), which further supports a CO-promoting role of Mtel. Again, this CO-promoting activity of Mte1 in the $s g s 1 \Delta$ and srs $2 \Delta$ mutants depends on the presence of Mph1 (Fig. 3B; Supplemental Fig. S2). Taken together, our results indicate that Mte1 promotes CO formation likely through antagonizing Mph1. Mtel is not required for efficient DSB repair (DSBR) in any of mutants tested here. Our biochemical analysis of Mte1, to be presented later, provides a mechanistic explanation for this Mtel function.

Mtel was previously found to form nuclear foci upon MMS treatment (Tkach et al. 2012). Given its pro-CO role at DSBs, we decided to examine possible DSB recruitment of Mte1. First, by fluorescence microscopy, we showed that Mte1-GFP forms a nuclear focus in response 
A

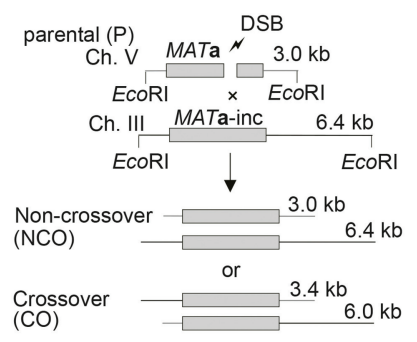

B

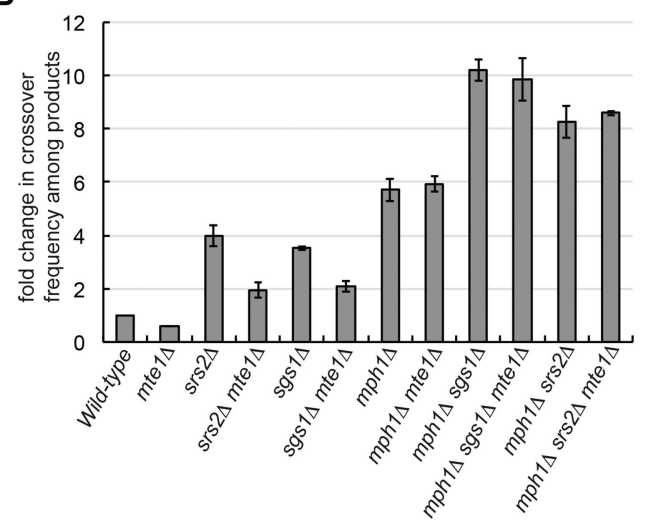

Figure 3. Pro-CO formation of MTE1 in mitotic cells. (A) Schematic of the ectopic recombination assay for determining $\mathrm{CO}$ and GC frequencies in DSB repair (DSBR). (B) Quantification of the CO frequency in different strains. The mean values $\pm S D$ from at least three independent experiments are plotted. $(C, D)$ Analysis of Mte1 recruitment to DSBs by fluorescence microscopy $(C)$ and chromatin immunoprecipitation $(\mathrm{ChIP})(D)$.

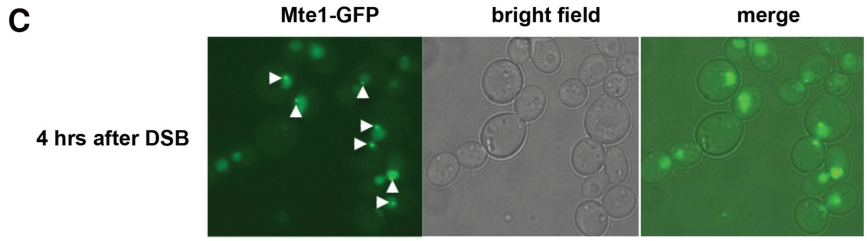

D

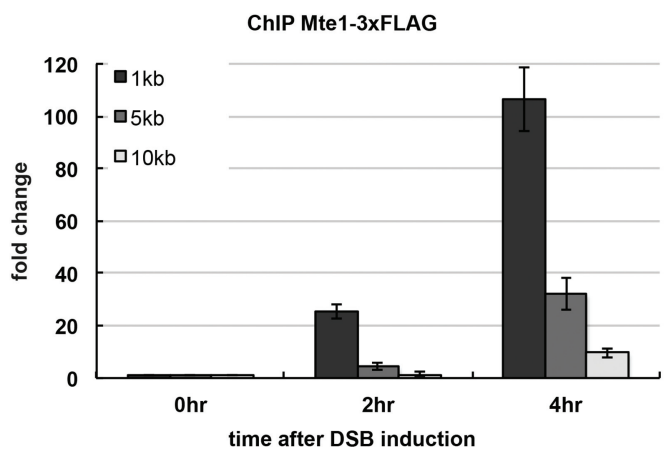

to a single nonrepairable DSB induced by the HO endonuclease (Fig. 3C). To verify that Mte1 is recruited to DSBs, we applied chromatin immunoprecipitation (ChIP) coupled with quantitative PCR (qPCR) and primers specific to sequences at 1,5 , or $10 \mathrm{~kb}$ from an HO-induced DSB to test recruitment of Flag-tagged Mte1. Importantly, the results revealed strong DSB recruitment of Mte1 (Fig. 3D). Thus, Mte1 forms nuclear foci after DNA damage and is recruited to DSBs-attributes that are characteristic of a protein factor involved in the DNA damage response.

\section{DNA structure-specific binding activity in Mte1}

Next, we performed a number of biochemical tests designed to understand how Mtel affects Mph1 functions. First, we examined whether Mte1 binds DNA. Using mobility shift of radiolabeled DNA as assay, we surveyed various types of DNA and found that Mte1 has nanomolar affinity for ssDNA, dsDNA, D loop, movable RF structure (MRF), and movable HJ structure (MHJ) (Supplemental Fig. S3). Mtel appears to have the highest affinity for the D loop, MHJ, and MRF, followed by ssDNA and dsDNA (Supplemental Fig. S3).
Isolation of functional domains in Mte1 and Mph1 and generation of mutants

To isolate the DNA-binding and Mph1 interaction domains in Mte1, we divided the protein into three segments that encompass amino acid residues 1-100, 101-200, and 201-271 and expressed them in insect cells. By testing the purified Mtel fragments in the DNA mobility shift assay (Fig. 4A; Supplemental Fig. S4A), we found that only Mte $1^{101-200}$ possesses D-loop-binding activity similar to that of full-length Mte1, suggesting that the DNA-binding domain of Mtel resides in this fragment (Supplemental Fig. S4C). In contrast, affinity pull-down revealed that only Mte $1^{201-271}$ is capable of interaction with Mph1-MHF (Supplemental Fig. S4B). The C-terminal region of Mph1 spanning residues 754-993 has been termed the regulatory domain (CTRD), as it confers the ability to interact with the MHF complex and the negative regulator Smc5 (Xue et al. 2014, 2015a). Importantly, affinity pulldown revealed that (1) the CTRD also interacts with Mte1-MHF avidly (Supplemental Fig. S1C), and (2) the truncation mutant mph1(1-754) that lacks the CTRD has little or no affinity for Mte1 (Supplemental Fig. S1C).

For the biochemical studies described below, we endeavored to generate mutants that are differentially 
A

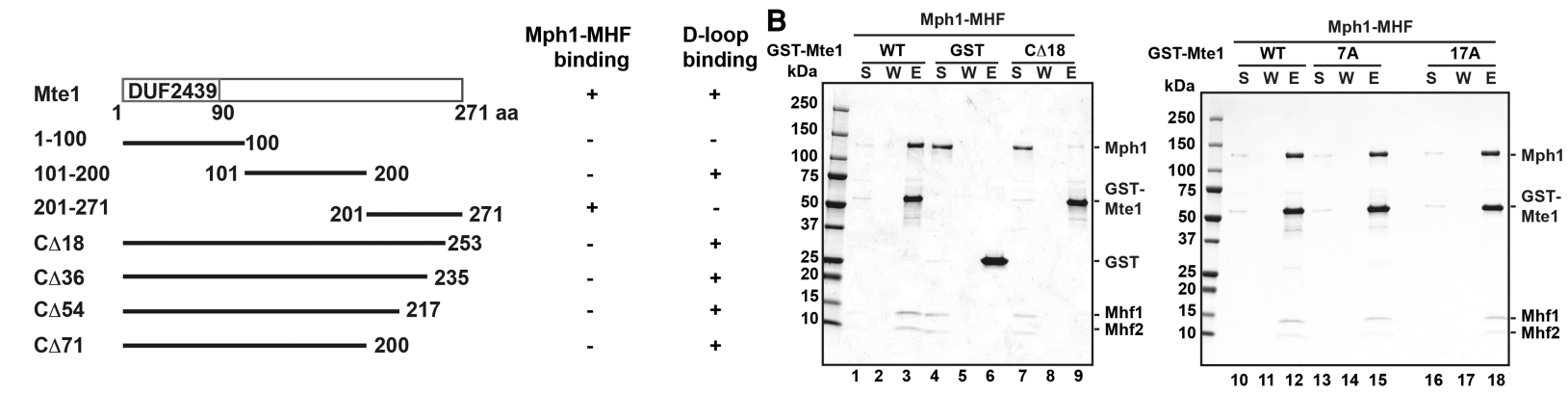

C
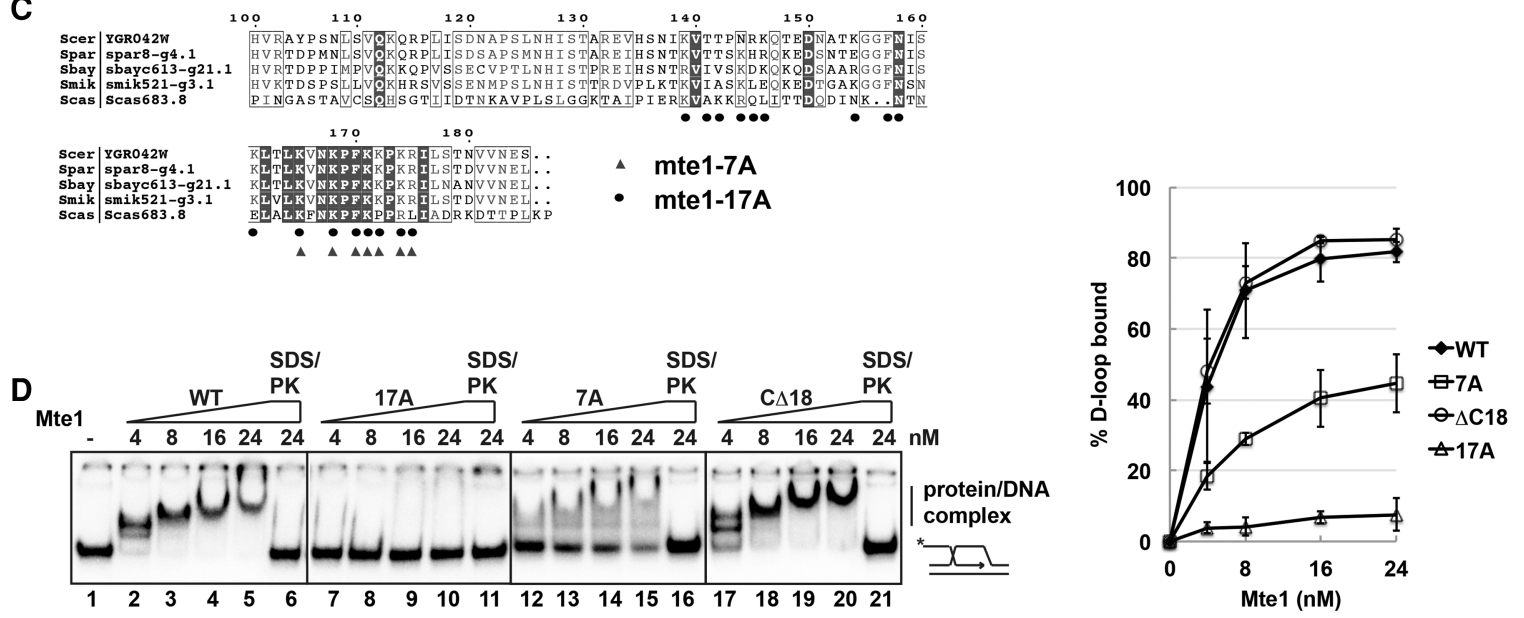

Figure 4. Mutants of Mte1 impaired for DNA binding or Mph1-MHF interaction. (A) Summary of mte1 truncation mutants tested to identify the Mph1-MHF interaction and D-loop-binding domains. (B) GST pull-down assay showing that mte1-C $\Delta 18$ is defective in interaction with Mph1-MHF, whereas the mte1-7A and mte1-17A mutants are proficient in this regard. (C) Alignment of the region of Mte1 spanning residues 100-184 against the equivalent region of orthologs from Saccharomyces species. The conserved residues that were changed to alanine to yield the 7A and 17A alleles are indicated by the triangles and circles, respectively. $(D)$ DNA mobility assay showing that the mte1-7A and mte1-17A mutants are compromised for D-loop binding, whereas the mte1-C $\Delta 18$ mutant is proficient. The mean values \pm SD from at least three independent experiments are plotted.

inactivated for either DNA binding or Mph1 interaction. Sequence alignment among Mte1 orthologs from Saccharomyces species revealed a conserved region (residues 165-175) within the middle portion of Mtel that we have shown to harbor the DNA-binding domain (Fig. 4A,C; Supplemental Fig. S4A). This region is rich in hydrophobic and lysine/arginine residues that could be involved in stacking interactions with the bases or charging interactions with the phosphodiester backbone in the DNA ligand, respectively. Seven of the conserved residues were replaced by alanine to yield the mte1-7A mutant (Fig. 4C). An additional 10 residues predicted to be involved in DNA binding by DP-Bind software (Hwang et al. 2007) were also mutated to yield the mte1-17A mutant (Fig. 4C). The two mutant proteins were expressed, purified, and tested for D-loop and MRF binding. The results revealed a severe defect in mte1-17A and a marked reduction in mte1-7A in DNA-binding activity (Fig. 4D; Supplemental Fig. S4D). We note that the nucleoprotein complexes made by mte1-7A appeared to be unstable (Fig. 4D; Supplemental Fig. S4D). Importantly, affinity pull-down tests showed that both mte1-7A and mte1$17 \mathrm{~A}$ retain the ability to interact with Mph1-MHF fully (Fig. 4B).
To generate an Mph1 interaction-defective mutant, we constructed a series of C-terminal truncations, deleting $18,36,54$, and 71 residues, respectively. These truncation mutants were expressed, purified, and tested for their ability to interact with Mph1-MHF. The results showed that deleting just the last 18 residues of Mte1 abolishes interaction with Mph1-MHF (Fig. 4B, left panel). The mte1 C $\Delta 18$ mutant is proficient in DNA binding (Fig. $4 \mathrm{D}$; Supplemental Fig. S4D).

\section{Enhancement of Mph1-mediated RF regression and DNA branch migration by Mte 1}

Results from our cell-based assays indicate that Mte1 differentially affects Mph1 function during RF repair and anti-CO control by promoting the former function but restraining the latter one. To provide mechanistic understanding of these differential effects, we examined how Mte1 affects known Mph1 activities in vitro. First, we tested the effect of Mtel in Mph1-mediated RF regression and DNA branch migration using a plasmid-based $\sigma$ shaped substrate that possesses the essential attributes of a RF. Regression of the substrate yields a HJ, which can branch-migrate $>2.9 \mathrm{~kb}$ to generate a radiolabeled 
linear product and an unlabeled circular one (Fig. 5A). Importantly, Mte1 alone or together with MHF enhanced Mph1-mediated RF regression and DNA branch migration about twofold (Fig. 5B, cf. lanes 1 and 3,13, and lanes 2 and 4,14). Control experiments confirmed that neither MHF nor Mtel possesses any RF regression activity (Supplemental Fig. S5A, right panel). Since RF regression catalyzed by either Mph1 or the Mph1-MHF-Mtel ensemble was equally sensitive to the addition of an unlabeled DNA trap (Supplemental Fig. S5B), Mtel does not appear to enhance the processivity of the RF regression reaction. These biochemical findings provide direct evidence for an involvement of Mtel in RF repair, as first suggested by genetic results (Fig. 2).

\section{Attenuation of Mph1-mediated D-loop dissociation} by Mte 1

The anti-CO function of Mph1 and its orthologs likely stems from the ability to disrupt the D-loop intermediate made by Rad51 so as to facilitate the engagement of the SDSA pathway during HR (Prakash et al. 2009). As Mte1 promotes CO formation only in cells that possess Mph1 (Fig. 3), we asked whether Mte1 affects the D-loop-dissociative attribute of Mph1 (Fig. 6A). Consistent with previous findings (Xue et al. 2015a), MHF had no effect on the
D-loop-dissociative activity of Mph1 (Fig. 6B). Important$1 y$, the inclusion of an amount of Mtel stoichiometric to that of Mph1 inhibited D-loop disruption (Fig. 6B), and the combination of Mte1 and MHF was more efficacious in this regard (Fig. 6B). Control experiments confirmed that neither Mte1 nor MHF alone affects the stability of Rad51-made D loops (Fig. 6B). Additional tests using oligonucleotide-based D-loop substrates bearing an invading ssDNA strand of either polarity showed that Mte1 is similarly able to attenuate the ability of $\mathrm{Mph} 1$ to dissociate this structure (Supplemental Fig. S6A,C) and verified that the yeast or human MHF complex exerts no influence on Mph1 (Supplemental Fig. S6B,D).

\section{Relevance of the Mph1-Mte1 complex and Mte1 DNA binding in the regulation of Mph1}

We proceeded to test the mte1 mutant proteins that we isolated to determine the roles of DNA binding and Mph1 interaction in RF regression and D-loop disruption. First, we observed that both mte1-17A and mte1-C $\Delta 18$ proteins are devoid of any stimulatory effect in Mph1-mediated RF regression (Fig. 5B). Thus, the interactions with DNA and Mph1 are indispensable for the function of Mte1 in RF regression. That complex formation between Mph1 and Mtel is necessary for functional synergy in RF regression
A

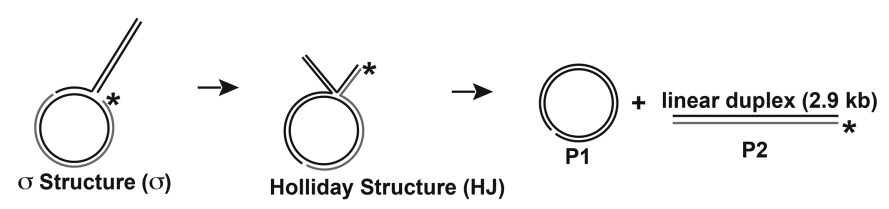

B

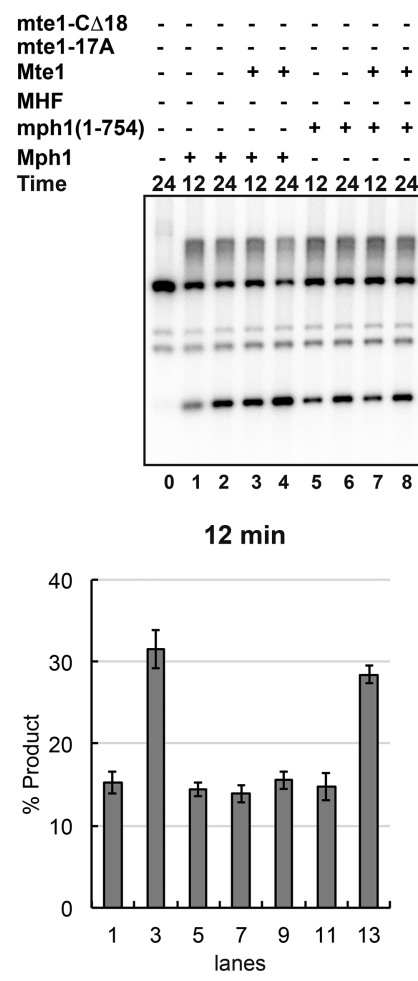

Figure 5. Enhancement of Mph1-mediated RF regression by Mte1. (A) Schematic showing processing of the $\sigma$ DNA substrate via regression and branch migration. The asterisk marks the radiolabeled DNA strand. (B) RF regression reactions catalyzed by Mph1 or the indicated mphl mutant in conjunction with MHF and Mte1 or the indicated mte1 mutant. Quantification of the linear duplex product from three independent experiments \pm SD is shown at the bottom. 

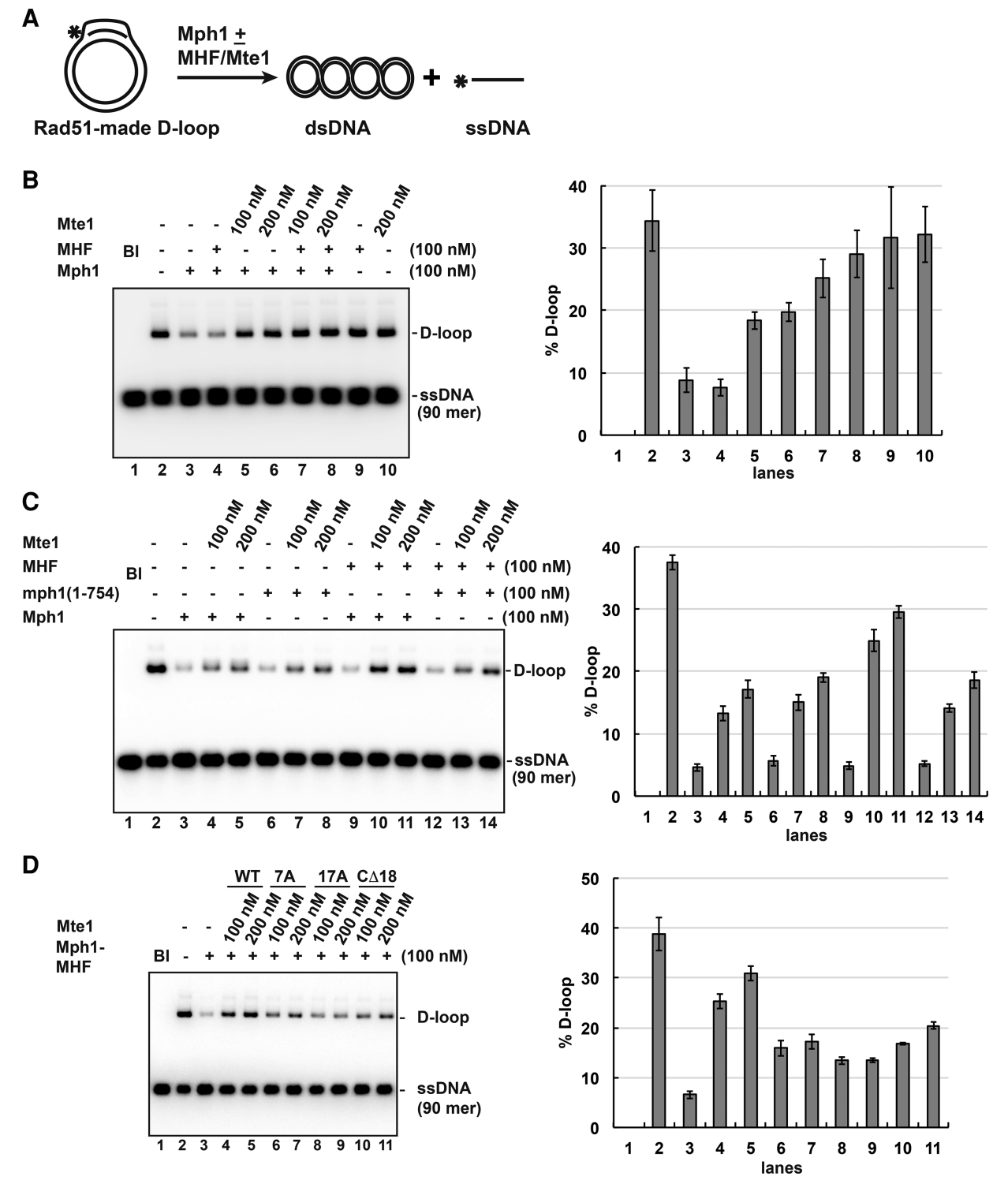

Figure 6. Attenuation of Mph1-mediated D-loop disruption by Mte1. (A) Schematic of the assay for examining the disruption of Rad51made D loops by Mph1 with and without Mte1 and MHF. (B) Mte1 was tested for its effect on the D-loop-disruptive activity of Mph1 or Mph1-MHF. (C) The effect of Mte1 on D-loop disruption by Mph1, mph1(1- 754) without or with MHF and Mph1-MHF. (D) Testing of mtel mutant proteins in the D-loop disruption reaction mediated by Mph1-MHF. In $B-D$, the percentage of D loop formed in each reaction was graphed as the average of triplicates \pm SD.

is substantiated by our finding that mph1(1-754), which is proficient in fork regression but deficient in Mte1 binding (Supplemental Fig. S1C), is unresponsive to Mtel (Fig. 5B).

Second, we tested the available mte1 and mph1 mutant proteins in the D-loop disruption reaction. As reported before (Xue et al. 2015a), mph1(1-754) was just as proficient in D-loop disruption as the wild-type protein (Fig. 6C). Interestingly, in the absence of MHF, Mtel exerted the same degree of inhibition of D-loop dissociation catalyzed by either Mph1 or mph1(1-754). However, with MHF being present, Mte1 was less adept at attenuating the Dloop-disruptive activity of mph1(1-754) than that of Mph1 (Fig. 6C). Since stable complex formation between
Mte1 and Mph1 requires MHF (Supplemental Fig. S1B), the results above suggested that, even though Mtel can attenuate Mph1-mediated D-loop disruption without contacting Mph1, complex formation between these proteins is nonetheless needed for maximal inhibition to occur. This conclusion was verified by examining the mtelC $\Delta 18$ mutant in conjunction with Mph1-MHF (Fig. 6D).

Results from additional experiments revealed that the mte1-7A and mte1-17A mutants are partially compromised for the ability to attenuate D-loop disruption that is mediated by Mph1-MHF, with mte1-17A being more severely impaired in this regard (Fig. 6D, cf. lanes 3 and $8,9)$. Therefore, in addition to Mph1-MHF interaction (Fig. 6C,D), the DNA-binding activity of Mtel is 
important for achieving optimal negative regulation of Mph1 in D-loop dissociation.

\section{Discussion}

The RF regression activity of the FANCM/Mph1/Fml1 family of DNA motor proteins is subject to positive and negative regulation so as to attain a fine balance between the necessity to prepare an injured RF for repair and also avoid the accumulation of toxic DNA intermediates stemming from further processing of the regressed fork. MHF stimulates this activity, while Smc5-Smc6 acts as a negative regulator (Singh et al. 2010; Yan et al. 2010; Bhattacharjee et al. 2013; Xue et al. 2014, 2015a). Thus far, no regulator of the D-loop-dissociative function of FANCM/Mph1/Fml1 has been found. In this study, we used an unbiased proteomic approach and in vivo and in vitro tests to reveal Mtel as a novel regulator of Mph1 in DSBR and RF repair.

Mte1 interacts with Mph1 and has high affinity for the $\mathrm{RF}, \mathrm{HI}$, and D loop. Mtel up-regulates Mph1 activity in RF regression and DNA branch migration in a manner that requires Mph1 interaction and DNA binding. Companion genetic analysis has furnished evidence that Mtel is part of the Mph1-dependent machinery involved in RF repair in cells. On the other hand, Mtel attenuates the ability of Mph1-MHF to disrupt D loops made by Rad51 and oligonucleotide-based D-loop substrates. Maximal inhibition is reliant on Mtel interaction with both DNA and Mph1-MHF. Importantly, in vivo assays have shown diminished CO formation in mte $1 \Delta$ cells, and this effect requires the presence of Mph1 but not Sgs1 and Srs2. These genetic results suggest a specific role of Mte1 as an antagonist of the D-loop-dissociative activity of Mphl in mitotic DSBR. We note that Lisby and colleagues (Silva et al. 2016) have independently reached a similar conclusion. We note that the pro-CO effect does not extend to meiosis, as we did not detect any role of MTE1 in meiotic CO control by genetic and DNA analyses (Supplemental Fig. S7). This lack of effect of Mte1 in meiotic HR likely stems from the absence of or low expression of Mphl during meiosis (Primig et al. 2000). We suspect that, for other eukaryotic organisms that express the Mph1 ortholog in meiotic cells, the functional equivalent of Mte1 therein would contribute to optimal CO formation (see below).

As shown in Figure 7A, our working model posits that Mte1 facilitates the processing of an injured RF by Mph1 to generate a regressed structure amenable to repair by HR or fork resetting (Whitby 2010; Xue et al. 2015b). In contrast, Mte1 antagonizes the D-loop-dissociative attribute of Mph1 to promote CO formation (Fig. 7B). To our knowledge, Mtel represents the first example of a protein that actively shunts the D-loop intermediate away from the SDSA pathway in favor of the CO-capable DSBR pathway (Fig. 7B). The N-terminal region of Mtel harbors the DUF2439 domain shared with the fission yeast Dbl2 protein (SPCC553.01c) and human ZGRF1 (C4orf21) protein. Several lines of evidence suggest that these fission yeast and human proteins are functionally related to Mte1. Spe- cifically, Dbl2 is needed for cellular resistance to the topoisomerase I poison camptothecin, forms DNA damageinduced foci, and is needed for the optimal recruitment of Fml1 to DNA damage (Han et al. 2010; Yu et al. 2013). Also, the meiotic chromosome segregation phenotype of the $d b 12 \Delta$ mutant suggests that the Dbl2 protein plays a role in meiotic HR. The human ZGRF1 protein has been linked to DNA cross-link repair in a genome-wide screen (Smogorzewska et al. 2010), and mutations of it have been found in a variety of human tumors (Cerami et al. 2012; Gao et al. 2013); otherwise, very little is known about its biological functions. Our work suggests that Dbl2 and ZGRF1 may be able to differentially regulate Fmll and FANCM, respectively, in a manner similar to what we found for Mte1 and should provide a valuable conceptual and experimental guide for these future endeavors.

\section{Materials and methods}

Expression and purification of Mte 1 and mutant mte1 proteins

The Mte1 protein-coding sequence was introduced into the pENTR D-TOPO vector (Invitrogen) and then transferred into the pDEST20 vector to produce the GST-(TEV)-Mte1 expression vector. A bacmid was generated in the Escherichia coli strain DH10Bac (Invitrogen) and used to transfect Sf9 insect cells (Invitrogen) to obtain a recombinant baculovirus. Hi5 insect cells (Invitrogen) were used for Mte 1 expression. All of the purification steps were conducted at $0^{\circ} \mathrm{C}-4^{\circ} \mathrm{C}$, and the elution of Mte 1 in various chromatographic steps was monitored by $12 \%$ SDS-PAGE and Coomassie blue staining of column fractions. A 12-g cell pellet (from $1 \mathrm{~L}$ of culture) was suspended in $100 \mathrm{~mL}$ of $\mathrm{K}$ buffer (20 $\mathrm{mM} \mathrm{KH}_{2} \mathrm{PO}_{4}$ at $\mathrm{pH} 7.4,10 \%$ glycerol, $0.5 \mathrm{mM}$ EDTA, $0.01 \%$ Igepal, $1 \mathrm{mMDTT}$ ) containing a cocktail of protease inhibitors $(5 \mu \mathrm{g} / \mathrm{mL}$ aprotinin, $5 \mu \mathrm{g} / \mathrm{mL}$ chymostatin, $5 \mu \mathrm{g} / \mathrm{mL}$ leupeptin, $5 \mu \mathrm{g} / \mathrm{mL}$ pepstatin $\mathrm{A}, 1 \mathrm{mM}$ phenyl-methylsulfonyl fluoride) and $150 \mathrm{mM} \mathrm{KCl}$. Cells were disrupted by sonication, and the crude lysate was subject to ultracentrifugation $(100,000 \mathrm{~g}$ for $90 \mathrm{~min})$. The clarified lysate was applied onto a $5-\mathrm{mL}$ column of SP Sepharose (GE Healthcare), which was washed with $50 \mathrm{~mL}$ of $\mathrm{K}$ buffer plus $150 \mathrm{mM} \mathrm{KCl}$ and then developed with a $100-\mathrm{mL}$ linear gradient from 150 to $550 \mathrm{mM} \mathrm{KCl}$. The peak of Mte1 protein, eluting at $\sim 400 \mathrm{mM} \mathrm{KCl}$, was collected and incubated with $1 \mathrm{~mL}$ of glutathione Sepharose 4B resin (GE Healthcare) for $1 \mathrm{~h}$. After washing the resin once with $50 \mathrm{~mL}$ of $\mathrm{K}$ buffer containing $1 \mathrm{M} \mathrm{KCl}$ and twice with $50 \mathrm{~mL}$ of $\mathrm{K}$ buffer containing $500 \mathrm{mM}$ $\mathrm{KCl}$, Mtel was eluted with $\mathrm{K}$ buffer with $500 \mathrm{mM} \mathrm{KCl}$ and $15 \mathrm{mM}$ reduced glutathione. To cleave the GST tag off Mte1, the protein pool was incubated with $40 \mu \mathrm{g}$ of TEV protease overnight at $4^{\circ} \mathrm{C}$. The reaction mixture was then passed through a $1-\mathrm{mL}$ column of glutathione Sepharose 4B twice to remove the cleaved GST, and the protein pool was concentrated to $500 \mu \mathrm{L}$ in an Ultracel-30K device (Amicon) and then fractionated in a $24-\mathrm{mL}$ column of Superdex 200 (GE Healthcare) in K buffer with $600 \mathrm{mM} \mathrm{KCl}$. Fractions containing Mte1 were collected, concentrated to $2 \mathrm{mg} / \mathrm{mL}$, and stored at $-80^{\circ} \mathrm{C}$ in $2-\mu \mathrm{L}$ aliquots. The yield of highly purified Mte1 was $400 \mu \mathrm{g}$. Expression and purification of mutant mte1 proteins followed the same procedures, with a similar overall yield of highly purified protein in each case.

\section{Expression and purification of Mte1 fragments}

The coding sequences for the three Mtel fragments (encompassing residues 1-100, 101-200, and 201-271, respectively) were 
Xue et al.

A

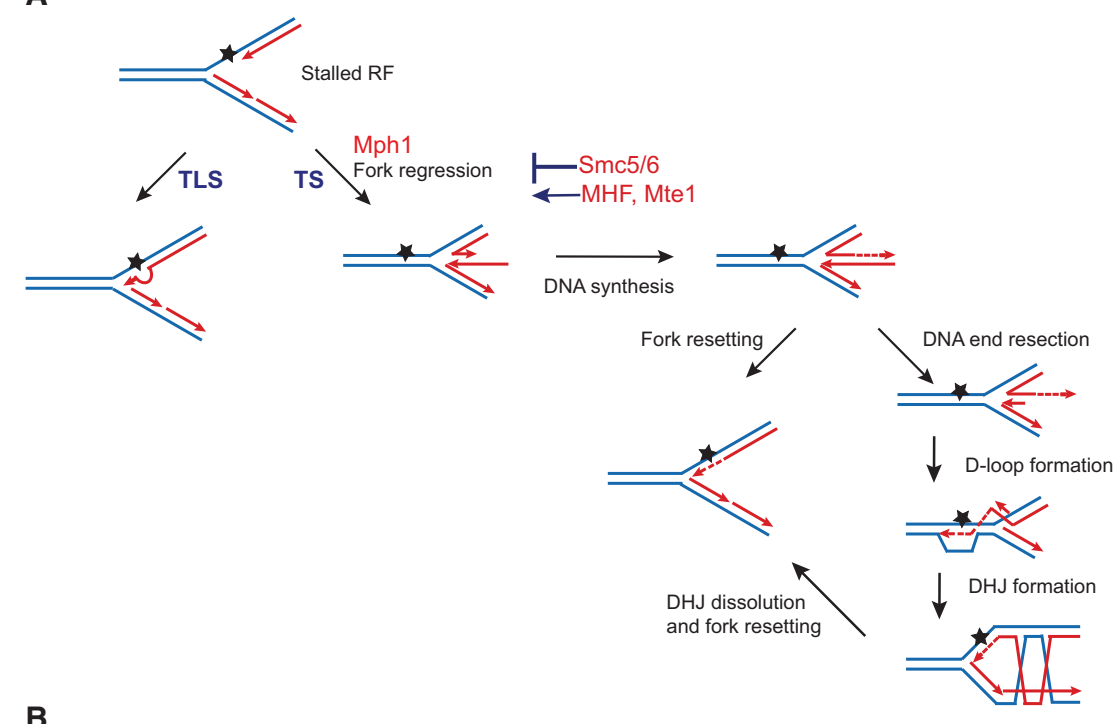

Figure 7. Models depicting the multifaceted role of Mtel in RF repair and CO promotion. (A) The role of Mtel in Mph1-mediated RF repair. (TLS) Translesion DNA synthesis; (TS) template switch; (DHJ) double HJ. For review, see Xue et al. (2015b). (B) During HR, Mte1 promotes $\mathrm{CO}$ formation by channeling the Rad51-made D-loop intermediate into the DSBR pathway. For review, see Xue et al. (2015b).

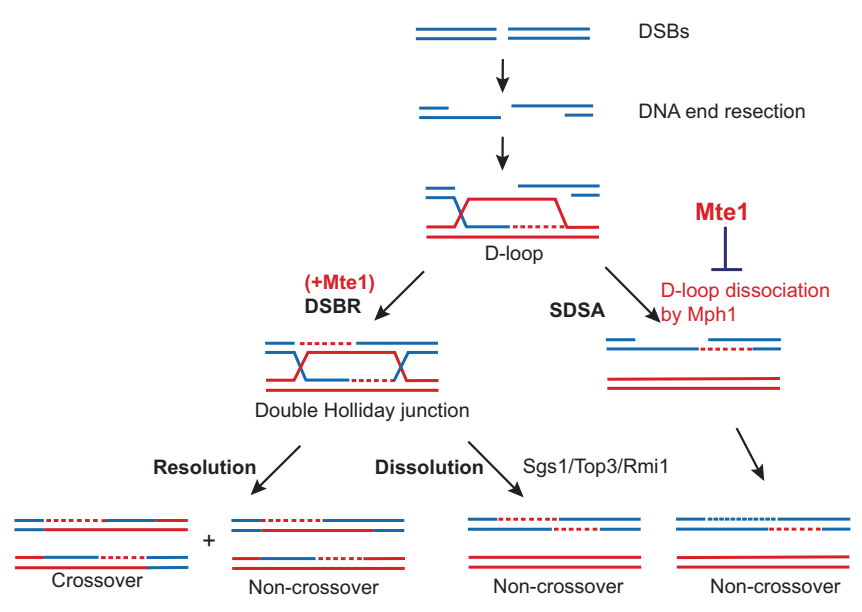

introduced into the pDEST20 vector to yield GST-(TEV)-Mte1 fragment expression vectors. The generation of bacmids and protein expression followed the procedures described above. The purification of Mte $1^{101-200}$ and Mte $1^{201-271}$ used the same procedure developed for full-length Mtel. The purification of Mte $1^{1-100}$ also followed the same procedure, except that the clarified lysate was fractionated in a $5-\mathrm{mL}$ Q Sepharose column instead of a SP Sepharose column.

Expression and purification of the Mph1-MHF-Mte1 and Mph1-MHF complexes

All of the protein purification steps were carried out at $0^{\circ} \mathrm{C}-4^{\circ} \mathrm{C}$. Hi5 insect cells individually expressing Mph1 (Xue et al. 2014), MHF (Xue et al. 2015a), and Mtel (this study) were mixed. The combined cell pellet $(\sim 11 \mathrm{~g}$, from $300 \mathrm{~mL}$ each of Mph1, MHF, and GST-Mte1 cultures) was resuspended in $100 \mathrm{~mL}$ of $\mathrm{K}$ buffer containing the cocktail of protease inhibitors and $250 \mathrm{mM} \mathrm{KCl}$. Cell lysate was prepared and clarified as described above. Next, the clarified lysate was diluted with 1 vol of K buffer and applied onto a $5-\mathrm{mL}$ SP Sepharose column, which was washed with 50 $\mathrm{mL}$ of $\mathrm{K}$ buffer plus $150 \mathrm{mM} \mathrm{KCl}$ and then developed with an 80 -mL linear gradient from 150 to $650 \mathrm{mM} \mathrm{KCl}$. Fractions containing the peak of the Mph1-MHF-Mte1 complex ( 450 mM
$\mathrm{KCl}$ ) were pooled and incubated with $0.5 \mathrm{~mL}$ of anti-Flag M2-agarose resin (Sigma) for $2 \mathrm{~h}$ at $4^{\circ} \mathrm{C}$ with gentle mixing. The resin was washed extensively with buffer $\mathrm{K}$ containing $250 \mathrm{mM} \mathrm{KCl}$ before eluting Mph1 and its associated proteins with $100 \mu \mathrm{g} / \mathrm{mL}$ Flag peptide (Sigma) in the same buffer. The eluted Mph1-MHFMtel complex was treated with $40 \mu \mathrm{g}$ of TEV protease for $10 \mathrm{~h}$ at $4^{\circ} \mathrm{C}$ to cleave the GST tag off Mtel. The reaction mixture was then passed through a 1-mL column of glutathione Sepharose 4B twice to remove the cleaved GST, and the flowthrough fraction was concentrated to $500 \mu \mathrm{L}$ and further resolved in a 24-mL Superdex 200 column in K buffer with $250 \mathrm{mM} \mathrm{KCl}$. The peak fractions corresponding to Mph1-MHF-Mtel were collected, concentrated to $\sim 0.5 \mathrm{mg} / \mathrm{mL}$, and stored at $-80^{\circ} \mathrm{C}$ in $2-\mu \mathrm{L}$ aliquots. The yield of highly purified Mph1-MHF-Mte1 complex was $\sim 100 \mu \mathrm{g}$. Assembly and purification of the Mph1-MHF complex followed the same procedure, except that the TEV cleavage step was omitted.

\section{Expression and purification of other proteins}

Expression and purification of Mph1, mph1(1-754), the Mph1 CTRD (residues 754-993), and human/budding yeast MHF followed our published procedures (Singh et al. 2010; Xue et al. 2014, 2015a). 


\section{Affinity pull-down assays}

For GST pull-down, $5 \mu \mathrm{g}$ of GST-tagged Mte1 or the indicated variant was incubated with $5 \mu \mathrm{g}$ of Mph1 or the indicated Mph1 fragment, MHF, or the Mph1-MHF complex in $30 \mu \mathrm{L}$ of $\mathrm{K}$ buffer with $150 \mathrm{mM} \mathrm{KCl}$ for $30 \mathrm{~min}$ at $4^{\circ} \mathrm{C}$. The reaction mixture was incubated with $10 \mu \mathrm{L}$ of glutathione Sepharose 4B resin (GE Healthcare Life Sciences) for $30 \mathrm{~min}$ at $4^{\circ} \mathrm{C}$. After washing the resin three times with $200 \mu \mathrm{L}$ of $\mathrm{K}$ buffer with $150 \mathrm{mM} \mathrm{KCl}$, bound proteins were eluted with $20 \mu \mathrm{L}$ of $2 \%$ SDS. Ten percent of the supernatant (S) and SDS elution (E) fractions and $2 \%$ of the wash (W) fraction were analyzed by $4 \%-20 \%$ gradient SDS-PAGE and Coomassie blue staining.

For Flag pull-down, $5 \mu \mathrm{g}$ of MHF was incubated with or without $5 \mu \mathrm{g}$ of Flag-tagged Mph1 in $30 \mu \mathrm{L}$ of $\mathrm{K}$ buffer with $150 \mathrm{mM} \mathrm{KCl}$ for $30 \mathrm{~min}$ at $4^{\circ} \mathrm{C}$. The reaction mixture was incubated with $10 \mu \mathrm{L}$ of anti-Flag agarose resin (Sigma) for $30 \mathrm{~min}$ at $4^{\circ} \mathrm{C}$. Washing, elution, and analysis followed the same procedure as above.

For MBP pull-down, $5 \mu \mathrm{g}$ of MBP-tagged Mph1(754-993) was incubated with $5 \mu \mathrm{g}$ of Mte1 and $5 \mu \mathrm{g}$ of MHF in $30 \mu \mathrm{L}$ of K buffer with $150 \mathrm{mM} \mathrm{KCl}$ for $30 \mathrm{~min}$ at $4^{\circ} \mathrm{C}$. The mixture was incubated with $10 \mu \mathrm{L}$ of amylose agarose resin (New England Biolabs) for $30 \mathrm{~min}$ at $4^{\circ} \mathrm{C}$. Washing, elution, and analysis followed the same procedure as above.

\section{DNA mobility shift assay}

In Supplemental Figure S3, 10-160 nM Mte1 was incubated with pairs of the indicated DNA substrates (10 $\mathrm{nM}$ each) for $10 \mathrm{~min}$ at $30^{\circ} \mathrm{C}$ in $10 \mu \mathrm{L}$ of buffer $\mathrm{D}(30 \mathrm{mM}$ Tris- $\mathrm{HCl}$ at $\mathrm{pH} 7.5,1 \mathrm{mM} \mathrm{DTT}$, $100 \mu \mathrm{g} / \mathrm{mL}$ BSA, $60 \mathrm{mM} \mathrm{KCl}$ ). In Figure 4D and Supplemental Figure S4D, 4-24 nM Mtel or mutant was incubated with $2 \mathrm{nM} 5^{\prime}$-Dloop or $2 \mathrm{nM}$ MRF for $10 \mathrm{~min}$ at $30^{\circ} \mathrm{C}$ in $10 \mu \mathrm{L}$ of buffer $\mathrm{D}$. The reaction mixtures were resolved in $6.5 \%$ polyacrylamide gels in TBE buffer (45 mM Tris-borate at $\mathrm{pH} 8.0,1 \mathrm{mM}$ EDTA) at $4^{\circ} \mathrm{C}$. Gels were dried onto Whatman DE81 paper (Whatman International Limited) and analyzed in a Personal Molecular Imager FX PhosphorImager (Bio-Rad).

\section{$R F$ regression assay}

Mph1 (2 nM), $2 \mathrm{nM} \mathrm{MHF,} \mathrm{and} 8 \mathrm{nM}$ Mte1 or the indicated mutant were incubated alone or in various combinations with $0.5 \mathrm{nM}$ Sigma DNA substrate for the indicated times at $30^{\circ} \mathrm{C}$ in $10 \mu \mathrm{L}$ of buffer A (25 mM Tris- $\mathrm{HCl}$ at pH 7.5, $1 \mathrm{mM} \mathrm{DTT,}, 100 \mu \mathrm{g} / \mathrm{mL}$ BSA, $45 \mathrm{mM} \mathrm{KCl}, 1 \mathrm{mM} \mathrm{MgCl} 2,2 \mathrm{mM} \mathrm{ATP}, 15 \mathrm{mM}$ phosphocreatine, $30 \mathrm{U} / \mathrm{mL}$ creatine phosphokinase). The reaction mixtures were deproteinized by treatment with $0.5 \%$ SDS and $0.5 \mathrm{mg} /$ $\mathrm{mL}$ proteinase $\mathrm{K}$ for $5 \mathrm{~min}$ at $37^{\circ} \mathrm{C}$ and then resolved in a $0.8 \%$ agarose gel in TBE buffer at $25^{\circ} \mathrm{C}$. Gels were dried and subjected to phosphorimaging analysis.

\section{D-loop disruption assays}

The D-loop reaction was conducted as described previously (Prakash et al. 2009; Zheng et al. 2011; Xue et al. 2014, 2015a). Briefly, $2.4 \mu \mathrm{M}$ nucleotides ${ }^{32} \mathrm{P}$-labeled 90 -mer ssDNA was incubated with $0.8 \mu \mathrm{M}$ Rad51 to assemble the Rad51-ssDNA nucleoprotein filament. Following the incorporation of $200 \mathrm{nM}$ RPA, $150 \mathrm{nM}$ Rad54, and $36 \mu \mathrm{M}$ base pairs pBluescript replicative form I dsDNA, the reaction was incubated for $4 \mathrm{~min}$ at $30^{\circ} \mathrm{C}$ to form $\mathrm{D}$ loops and then left on ice. In Figure 6B, the reaction mixture that contained Rad51-made D loops was further incubated for

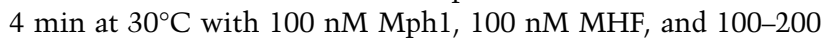
$\mathrm{nM}$ Mtel or the indicated combinations of these proteins.
In Figure 6, C and D, the D-loop reaction was further incubated

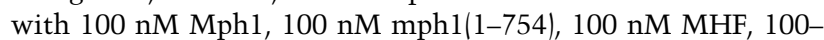
$200 \mathrm{nM}$ wild-type Mte1, 100-200 nM the specified mte1 mutant, or the indicated combinations of these proteins, as above. The reaction mixtures were deproteinized before being resolved in $0.9 \%$ agarose gels in TBE buffer. Gels were dried, and the radiolabeled DNA species were revealed and quantified by phosphorimaging analysis.

In Supplemental Figure S6, the D-loop substrates with either a $5^{\prime}$ or $3^{\prime}$ invading strand were made by hybridizing oligonucleotides, as described before (Prakash et al. 2009). These substrates $(5 \mathrm{nM})$ were incubated for $10 \mathrm{~min}$ at $30^{\circ} \mathrm{C}$ with $40 \mathrm{nM} \mathrm{Mph} 1$, 80-160 nM yeast or human MHF, and 80-160 nM Mte1 or the indicated combinations of these proteins. The reaction mixtures were analyzed as above.

\section{Measurement of MMS sensitivity}

Strain construction and yeast cultures followed standard procedures. The smc6-P4 mutant strain harbors the K239R mutation in the SMC6 gene (Chen et al. 2009; Xue et al. 2015a). For damage sensitivity tests, 10-fold serial dilutions of log-phase cultures were spotted on plates with the indicated concentration of MMS (Chen et al. 2009; Xue et al. 2015a).

\section{Determination of mitotic CO frequency by Southern blot analysis}

The method that monitors the efficiency of the repair of a sitespecific DSB induced by the $\mathrm{HO}$ endonuclease and the $\mathrm{NCO} /$ $\mathrm{CO}$ frequency during the repair process has been described (Prakash et al. 2009; Xue et al. 2015a). To determine the CO frequency among recombination products, DNA isolated from cells $8 \mathrm{~h}$ after $\mathrm{HO}$ endonuclease induction was digested with the restriction enzyme EcoRI and resolved in a $0.8 \%$ agarose gel. The digested DNA was transferred to a Nylon ${ }^{+}$membrane and hybridized with the MATa probe corresponding to 200 base pairs (bp) on each side of the HO cut site. The intensity of bands corresponding to the NCO and CO products was normalized against that of the APA1 gene.

\section{Fluorescence microscopy}

Live-cell photographs were captured $4 \mathrm{~h}$ after DSB induction using an EM-CCD digital camera (Hamamatsu) connected to an Axiovert 200M microscope (Zeiss) with a Plan-Apochromat 1.4 N.A. 100× objective lens and an EGFP filter (Chroma, no. 41017).

\section{ChIP}

ChIP was done as described previously (Chen et al. 2012). In brief, strain yXC713 (MATa ho hml::ADE1 hmr::ADE1 ade1-100 leu23,112 lys5 trp1::hisG ura3-52 ade3::GAL10::HO cdc28-as1 MTE1-3Flag-KanMX) was grown to a density of $1 \times 10^{7}$ cells per milliliter in YEP raffinose medium. DSBs were generated by the addition of galactose (final concentration of $2 \%$ ) to induce $\mathrm{HO}$ endonuclease. A 40-mL aliquot was collected for each time point, and formaldehyde (final concentration of $1 \%$ ) was added to cross-link proteins to DNA. After a 10-min incubation at room temperature, the reaction was quenched by the addition of glycine (final concentration of $125 \mathrm{mM}$ ). Cells were lysed with glass beads in a bead beater in $1 \times$ lysis buffer $(50 \mathrm{mM}$ HEPES/NaOH at $\mathrm{pH} 7.5,140 \mathrm{mM} \mathrm{NaCl}, 1 \mathrm{mM}$ EDTA, $0.1 \%$ sodium deoxycholate, $1 \%$ Triton X-100) supplemented with protease inhibitors followed by a sonication step to shear DNA (average size $0.5 \mathrm{~kb}$ ). 
Cell debris was removed by centrifugation, $3 \mu \mathrm{g}$ of anti-Flag antibody (M2, Sigma) was added, and samples were incubated overnight at $40^{\circ} \mathrm{C}$. Then, $50 \mu \mathrm{L}$ of protein $\mathrm{G}$ resin (Roche) was added followed by $4 \mathrm{~h}$ of incubation at $40^{\circ} \mathrm{C}$. The eluted complex was eluted and incubated overnight at $65^{\circ} \mathrm{C}$ to reverse protein-DNA cross-linking, and the samples were further treated with proteinase $\mathrm{K}$ for $6 \mathrm{~h}$ followed by phenol-chloroform extraction and ethanol precipitation of the DNA. The precipitated DNA was analyzed by real-time qPCR (ABI, 7900HT) with primer pairs A and B for $1 \mathrm{~kb}$ from the DSB, C and D for $5 \mathrm{~kb}$ from the DSB, and $\mathrm{E}$ and $\mathrm{F}$ for $10 \mathrm{~kb}$ from the DSB. Primers A-F were as follows: primer A, 5'GGTAGGCGAGGACATTATCTATCA-3'; primer B, 5'-GAAG AATACCAGTTTATCTCGCATTCAAATC-3'; primer C, 5' -CC TGTGATGTGTAATGGAATGGC-3' ${ }^{\prime}$; primer D, 5'-CAAGTAT

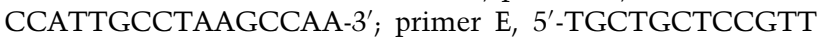
GTTCGAGC-3'; and primer F, 5'-GGCAGTGATGGCGTATAG CACAG-3'.

\section{Determination of meiotic $C O$ and $G C$ frequencies}

Sporulation, DNA preparation and digestion, Southern blotting, and quantification have been described (Allers and Lichten 2000; Jessop and Lichten 2008; De Muyt et al. 2012), as have the construction of the recombination reporter strains and tetrad dissection (Jessop et al. 2005). Data for wild type are from MJL2902 (Jessop et al. 2005), which harbors an insert at HIS4 that is marked with the ura3-pal and arg4-pal alleles, both of which contain a short palindrome insert that is refractory to mis-

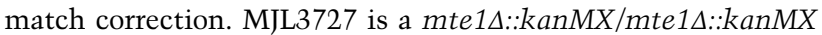
diploid that is otherwise isogenic with MJL2902, except that the insert at HIS4 is URA3-arg4-pal. For the purpose of this study, only gene conversion events involving arg4-pal were considered.

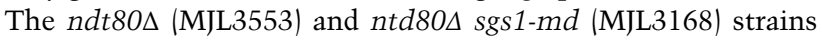
have been described (Jessop and Lichten 2008; De Muyt et al. 2012); MJL3720 is isogenic to MJL3168 but is also mte14:: kanMX/mte14::kanMX.

\section{Acknowledgments}

We acknowledge Dr. Kazuishi Kubota and Dr. Steven Gygi (Harvard Medical School) for their help in mass spectrometry. This study was supported by US National Institutes of Health grants ES007061, ES015252, ES015632, GM057814, GM080600, and GM080670 and the Intramural Research Program of the National Institutes of Health through the Center for Cancer Research at the National Cancer Institute.

\section{References}

Allers T, Lichten M. 2000. A method for preparing genomic DNA that restrains branch migration of Holliday junctions. Nucleic Acids Res 28: e6.

Bakker ST, van de Vrugt HJ, Rooimans MA, Oostra AB, Steltenpool J, Delzenne-Goette E, van der Wal A, van der Valk $M$, Joenje $\mathrm{H}$, te Riele $\mathrm{H}$, et al. 2009. Fancm-deficient mice reveal unique features of Fanconi anemia complementation group M. Hum Mol Genet 18: 3484-3495.

Bhattacharjee S, Osman F, Feeney L, Lorenz A, Bryer C, Whitby MC. 2013. MHF1-2/CENP-S-X performs distinct roles in centromere metabolism and genetic recombination. Open Biol 3: 130102.

Blackford AN, Schwab RA, Nieminuszczy J, Deans AJ, West SC, Niedzwiedz W. 2012. The DNA translocase activity of
FANCM protects stalled replication forks. Hum Mol Genet 21: 2005-2016.

Cejka P, Plank JL, Bachrati CZ, Hickson ID, Kowalczykowski SC. 2010. Rmil stimulates decatenation of double Holliday junctions during dissolution by Sgs1-Top3. Nat Struct Mol Biol 17: 1377-1382.

Cerami E, Gao J, Dogrusoz U, Gross BE, Sumer SO, Aksoy BA, Jacobsen A, Byrne CJ, Heuer ML, Larsson E, et al. 2012. The cBio cancer genomics portal: an open platform for exploring multidimensional cancer genomics data. Cancer Discov 2: 401-404.

Chavez A, Agrawal V, Johnson FB. 2011. Homologous recombination-dependent rescue of deficiency in the structural maintenance of chromosomes (Smc) 5/6 complex. J Biol Chem 286: 5119-5125.

Chen YH, Choi K, Szakal B, Arenz J, Duan X, Ye H, Branzei D, Zhao X. 2009. Interplay between the Smc5/6 complex and the Mph1 helicase in recombinational repair. Proc Natl Acad Sci 106: 21252-21257.

Chen X, Cui D, Papusha A, Zhang X, Chu CD, Tang J, Chen K, Pan X, Ira G. 2012. The Fun30 nucleosome remodeller promotes resection of DNA double-strand break ends. Nature 489: 576-580.

Choi K, Szakal B, Chen YH, Branzei D, Zhao X. 2010. The Smc5/6 complex and Esc2 influence multiple replication-associated recombination processes in Saccharomyces cerevisiae. Mol Biol Cell 21: 2306-2314.

Daee DL, Ferrari E, Longerich S, Zheng XF, Xue X, Branzei D, Sung P, Myung K. 2012. Rad5-dependent DNA repair functions of the Saccharomyces cerevisiae FANCM protein homolog Mph1. J Biol Chem 287: 26563-26575.

Deans AJ, West SC. 2009. FANCM connects the genome instability disorders Bloom's syndrome and Fanconi anemia. Mol Cell 36: $943-953$.

De Muyt A, Jessop L, Kolar E, Sourirajan A, Chen J, Dayani Y, Lichten M. 2012. BLM helicase ortholog Sgs1 is a central regulator of meiotic recombination intermediate metabolism. Mol Cell 46: 43-53.

Gao J, Aksoy BA, Dogrusoz U, Dresdner G, Gross B, Sumer SO, Sun Y, Jacobsen A, Sinha R, Larsson E, et al. 2013. Integrative analysis of complex cancer genomics and clinical profiles using the cBioPortal. Sci Signal 6: pll.

Gari K, Decaillet C, Delannoy M, Wu L, Constantinou A. 2008a. Remodeling of DNA replication structures by the branch point translocase FANCM. Proc Natl Acad Sci 105: 16107-16112.

Gari K, Decaillet C, Stasiak AZ, Stasiak A, Constantinou A. 2008b. The Fanconi anemia protein FANCM can promote branch migration of Holliday junctions and replication forks. Mol Cell 29: 141-148.

Han TX, Xu XY, Zhang MJ, Peng X, Du LL. 2010. Global fitness profiling of fission yeast deletion strains by barcode sequencing. Genome Biol 11: R60.

Hwang S, Gou Z, Kuznetsov IB. 2007. DP-Bind: a Web server for sequence-based prediction of DNA-binding residues in DNA-binding proteins. Bioinformatics 23: 634-636.

Ira G, Malkova A, Liberi G, Foiani M, Haber JE. 2003. Srs2 and Sgs1-Top3 suppress crossovers during double-strand break repair in yeast. Cell 115: 401-411.

Jessop L, Lichten M. 2008. Mus81/Mms4 endonuclease and Sgs1 helicase collaborate to ensure proper recombination intermediate metabolism during meiosis. Mol Cell 31: 313-323.

Jessop L, Allers T, Lichten M. 2005. Infrequent co-conversion of markers flanking a meiotic recombination initiation site in Saccharomyces cerevisiae. Genetics 169: 1353-1367. 
Kim H, D'Andrea AD. 2012. Regulation of DNA cross-link repair by the Fanconi anemia/BRCA pathway. Genes Dev 26: 1393-1408.

Kottemann MC, Smogorzewska A. 2013. Fanconi anaemia and the repair of Watson and Crick DNA crosslinks. Nature 493: 356-363.

Krejci L, Van Komen S, Li Y, Villemain J, Reddy MS, Klein H, Ellenberger T, Sung P. 2003. DNA helicase Srs2 disrupts the Rad51 presynaptic filament. Nature 423: 305-309.

Longerich S, Li J, Xiong Y, Sung P, Kupfer GM. 2014. Stress and DNA repair biology of the Fanconi anemia pathway. Blood 124: 2812-2819.

Luke-Glaser S, Luke B, Grossi S, Constantinou A. 2010. FANCM regulates DNA chain elongation and is stabilized by S-phase checkpoint signalling. EMBO J 29: 795-805.

Meetei AR, Medhurst AL, Ling C, Xue Y, Singh TR, Bier P, Steltenpool J, Stone S, Dokal I, Mathew CG, et al. 2005. A human ortholog of archaeal DNA repair protein Hef is defective in Fanconi anemia complementation group M. Nat Genet 37: 958-963.

Mosedale G, Niedzwiedz W, Alpi A, Perrina F, Pereira-Leal JB, Johnson M, Langevin F, Pace P, Patel KJ. 2005. The vertebrate Hef ortholog is a component of the Fanconi anemia tumorsuppressor pathway. Nat Struct Mol Biol 12: 763-771.

Niu H, Chung WH, Zhu Z, Kwon Y, Zhao W, Chi P, Prakash R, Seong C, Liu D, Lu L, et al. 2010. Mechanism of the ATP-dependent DNA end-resection machinery from Saccharomyces cerevisiae. Nature 467: 108-111.

Prakash R, Satory D, Dray E, Papusha A, Scheller J, Kramer W, Krejci L, Klein H, Haber JE, Sung P, et al. 2009. Yeast Mph1 helicase dissociates Rad51-made D-loops: implications for crossover control in mitotic recombination. Genes Dev 23: 67-79.

Primig M, Williams RM, Winzeler EA, Tevzadze GG, Conway AR, Hwang SY, Davis RW, Esposito RE. 2000. The core meiotic transcriptome in budding yeasts. Nat Genet 26: 415-423.

Rigaut G, Shevchenko A, Rutz B, Wilm M, Mann M, Seraphin B. 1999. A generic protein purification method for protein complex characterization and proteome exploration. Nat Biotechnol 17: 1030-1032.

Rosado IV, Niedzwiedz W, Alpi AF, Patel KJ. 2009. The Walker B motif in avian FANCM is required to limit sister chromatid exchanges but is dispensable for DNA crosslink repair. Nucleic Acids Res 37: 4360-4370.

Scheller J, Schurer A, Rudolph C, Hettwer S, Kramer W. 2000. $M P H 1$, a yeast gene encoding a DEAH protein, plays a role in protection of the genome from spontaneous and chemically induced damage. Genetics 155: 1069-1081.

Schurer KA, Rudolph C, Ulrich HD, Kramer W. 2004. Yeast $M P H 1$ gene functions in an error-free DNA damage bypass pathway that requires genes from homologous recombination, but not from postreplicative repair. Genetics 166: 1673-1686.

Schwab RA, Blackford AN, Niedzwiedz W. 2010. ATR activation and replication fork restart are defective in FANCM-deficient cells. EMBO J 29: 806-818.

Silva S, Altmannova V, Luke-Glaser S, Henriksen P, Gallina I, Yang X, Choudhary C, Luke B, Krejci L, Lisby M. 2016. Mte1 interacts with Mph1 and promotes crossover recombi- nation and telomere maintenance. Genes Dev (this issue). doi: 10.1101/gad.276204.115.

Singh TR, Bakker ST, Agarwal S, Jansen M, Grassman E, Godthelp BC, Ali AM, Du CH, Rooimans MA, Fan Q, et al. 2009. Impaired FANCD2 monoubiquitination and hypersensitivity to camptothecin uniquely characterize Fanconi anemia complementation group M. Blood 114: 174-180.

Singh TR, Saro D, Ali AM, Zheng XF, Du CH, Killen MW, Sachpatzidis A, Wahengbam K, Pierce AJ, Xiong Y, et al. 2010. MHF1-MHF2, a histone-fold-containing protein complex, participates in the Fanconi anemia pathway via FANCM. Mol Cell 37: 879-886.

Smogorzewska A, Desetty R, Saito TT, Schlabach M, Lach FP, Sowa ME, Clark AB, Kunkel TA, Harper JW, Colaiacovo MP, et al. 2010. A genetic screen identifies FAN1, a Fanconi anemia-associated nuclease necessary for DNA interstrand crosslink repair. Mol Cell 39: 36-47.

Sun W, Nandi S, Osman F, Ahn JS, Jakovleska J, Lorenz A, Whitby MC. 2008. The FANCM ortholog Fmll promotes recombination at stalled replication forks and limits crossing over during DNA double-strand break repair. Mol Cell 32: 118-128.

Tkach JM, Yimit A, Lee AY, Riffle M, Costanzo M, Jaschob D, Hendry JA, Ou J, Moffat J, Boone C, et al. 2012. Dissecting DNA damage response pathways by analysing protein localization and abundance changes during DNA replication stress. Nat Cell Biol 14: 966-976.

Wang AT, Smogorzewska A. 2015. SnapShot: Fanconi anemia and associated proteins. Cell 160: 354-354 e351.

Whitby MC. 2010. The FANCM family of DNA helicases/translocases. DNA Repair (Amst) 9: 224-236.

Wu L, Hickson ID. 2003. The Bloom's syndrome helicase suppresses crossing over during homologous recombination. $\mathrm{Na}$ ture 426: 870-874.

Wyatt HD, West SC. 2014. Holliday junction resolvases. Cold Spring Harb Perspect Biol 6: a023192.

Xue X, Choi K, Bonner J, Chiba T, Kwon Y, Xu Y, Sanchez H, Wyman C, Niu H, Zhao X, et al. 2014. Restriction of replication fork regression activities by a conserved SMC complex. Mol Cell 56: 436-445.

Xue X, Choi K, Bonner JN, Szakal B, Chen YH, Papusha A, Saro D, Niu H, Ira G, Branzei D, et al. 2015a. Selective modulation of the functions of a conserved DNA motor by a histone fold complex. Genes Dev 29: 1000-1005.

Xue X, Sung P, Zhao X. 2015b. Functions and regulation of the multitasking FANCM family of DNA motor proteins. Genes Dev 29: 1777-1788.

Yan Z, Delannoy M, Ling C, Daee D, Osman F, Muniandy PA, Shen X, Oostra AB, Du H, Steltenpool J, et al. 2010. A histone-fold complex and FANCM form a conserved DNA-remodeling complex to maintain genome stability. Mol Cell 37: 865-878.

Yu Y, Ren JY, Zhang JM, Suo F, Fang XF, Wu F, Du LL. 2013. A proteome-wide visual screen identifies fission yeast proteins localizing to DNA double-strand breaks. DNA Repair (Amst) 12: 433-443.

Zheng XF, Prakash R, Saro D, Longerich S, Niu H, Sung P. 2011. Processing of DNA structures via DNA unwinding and branch migration by the $S$. cerevisiae Mph1 protein. DNA Repair (Amst) 10: 1034-1043. 


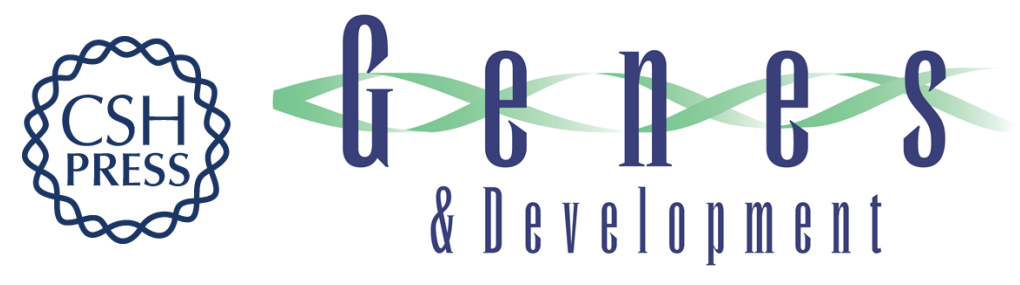

\title{
Differential regulation of the anti-crossover and replication fork regression activities of Mph1 by Mte1
}

\author{
Xiaoyu Xue, Alma Papusha, Koyi Choi, et al. \\ Genes Dev. 2016, 30: originally published online March 10, 2016 \\ Access the most recent version at doi:10.1101/gad.276139.115
}

\section{Supplemental http://genesdev.cshlp.org/content/suppl/2016/03/08/gad.276139.115.DC1 \\ Material}

Related Content Mte1 interacts with Mph1 and promotes crossover recombination and telomere maintenance

Sonia Silva, Veronika Altmannova, Sarah Luke-Glaser, et al.

Genes Dev. March , 2016 30: 700-717

References This article cites 52 articles, 20 of which can be accessed free at: http://genesdev.cshlp.org/content/30/6/687.full.html\#ref-list-1

Articles cited in: http://genesdev.cshlp.org/content/30/6/687.full.htmI\#related-urls

Creative This article is distributed exclusively by Cold Spring Harbor Laboratory Press for the first Commons six months after the full-issue publication date (see

License http://genesdev.cshlp.org/site/misc/terms.xhtml). After six months, it is available under a Creative Commons License (Attribution-NonCommercial 4.0 International), as described at http://creativecommons.org/licenses/by-nc/4.0/.

Email Alerting Receive free email alerts when new articles cite this article - sign up in the box at the top Service right corner of the article or click here.

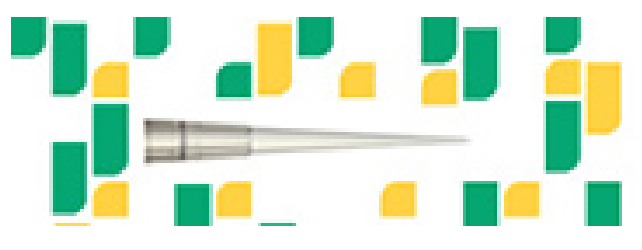

Focused on your science. 